\title{
Modulation of Matrix Metalloproteinases in Sjogren's Syndrome by Proinflammatory Cytokines.
}

\author{
Enamul Kabir1, Nick Di Girolamo2, Denis Wakefield3
}

\begin{abstract}
The pathogenesis of Primary Sjogren's syndrome (pSS) is not yet clearly known. PSS is characterized by dryness of mouth and eyes. The matrix metalloproteinase are proteolytic enzymes involved in degradation of extracellular matrix and implicated in the pathogenesis of many autoimmune diseases including Sjogren's syndrome. The purpose of current study was to determine whether MMPs (matrix metallooproteinases)-1, 2, 3, 9 expressions are induced by proinflammatory cytokines using a human salivary gland duct cell line. A neoplastic epithelial duct cell line (Human Salivary Gland cell line-HSG cells) established from an irradiated human submandibular salivary gland which mimic specific in vivo features of SS was used to perform the current study. We tried to determine whether $I L-1 \beta$ and TNF- $\alpha$, its combination induce the production of MMPs-1, 2, 3, 9. Analyses of supernatant from cytokine treated cells were done by SDS-PAGE Zymography and Western blotting. Increased $92 \mathrm{kDa}$ gelatinase activity was detected in cytokine treated cells compared to untreated HSG cells and activity were highest in IL-1 13 treated cells compared to individually treated cells by TNF- $\alpha$ and its combination with IL-1 $\beta$. Western blotting confirmed the modulatory effect of $I L-1 \beta$ and TNF- $\alpha$ on MMP-1, MMP-3 production. The proinflammatory cytokines have been found to induce expression of matrix metalloproteinases in many autoimmune diseases including Sjogren's syndrome. Our study corroborated the previous study of presence of gelatinolytic MMP induction by proinflammatory cytokine in this cell line. Our study confirmed for the first time the increased expression of MMP-1 and MMP-3 protein band in cytokine treated cells compared to untreated HSG cells. So, we conclude that proinflammatory cytokines IL-1 $\beta$ and TNF- $\alpha$ modulate the expression of MMPs in SS.
\end{abstract}

Keywords: Sjogren's syndrome, Matrixmetalloproteinases (MMPs), Proinflammatory cytokines.

\section{Introduction}

The pathogenesis of primary Sjogren's syndrome is not clearly known. But this autoimmune disease is not uncommon affecting 1-3\% of general population. This is a disease of middle age with female preponderance $(90 \%)$ but can occur at any age 1,2 with predominant clinical complaints of dryness of mouth and eyes.

Matrix metalloproteinase are proteolytic enzymes involved in degradation of extracellular matrix and have been implicated in the pathogenesis of many autoimmune diseases including Sjogren's syndrome ${ }^{3,4}$. The proinflammatory cytokines have been found to induce expression of matrix metalloproteinases in Sjogren's syndrome using HSG cell (Human Salivary Gland cell line) line ${ }^{3}$. The purpose of current in vitro study was to determine whether MMP-1, 2, 3, 9 expressions are induced by proinflammatory cytokines (IL-1 and TNF- $\alpha$ ) using a human epithelial duct cell line (Human Salivary Gland cell line) which mimics many characteristics of Sjogren's syndrome.

\section{Materials and methods:}

The human salivary gland cell line (HSG) was derived from a histologically normal submandibular gland that had been irradiated. This cell line assumed characteristic of intercalated duct cells 5 . The intercalated duct cells have the ability to differentiate into acinar like cells 6 . HSG cells mimic many features of SS. It is a most suitable cell line currently available to examine SS as evidenced by its capability to express increased ICAM-1, HLA-DR expression, increased secretion of IL-67,8. It has been shown that long-term exposure of HSG cells to IFN-g +/- TNF-a leads to increased cell death7. Furthermore, cytokine treatment (IFN- $\gamma$ and TNF- $\alpha$ ) of HSG cells assumed features of diseased salivary glands, such as increased expression of IL-1, and increased epithelial cell apoptosis ${ }^{9}$. HSG cells show functionally coupled neuroreceptors, intact calcium signaling system required to move salivary fluid naturally and ion channels for generation of osmotic gradients. In addition, these cells are responsive to

\section{Dr. Enamul Kabir, Assistant Professor of Pathology, Sir Salimullah Medical College, Dhaka.}

2. Dr. Nick Di Girolamo, Post doctoral research fellow, School of Pathology, The University of New South Wales, Sydney, Australia.

3. Professor Denis Wakefield, Head of School of Pathology and Associate Dean (Teaching \& curriculum), The University of New South Wales, Sydney, Australia. 
various signals from experimental matrices in the tissue culture plastic, which can be used to study morphological differentiation and differentiated pattern of gene expression 10 . The HSG cell line is a useful tool to examine various aspects of SS.

HSG cells (a kind gift of Prof. Mitsunobu Sato, Tokushima University, School of Dentistry, Japan) were cultured in the presence of $10 \%$ FBS (CSL. Melbourne, VIC) and EMEM (Trace Bioscience, Sydney, Australia) until they reached confluence. Cells were then seeded $\left(1 \times 10^{6}\right.$ cells / flask) in 75$\mathrm{cm}^{2}$ culture flask (Techno plastic products AG, Trasadingen, Switzerland) and grown to semiconfluence. At this stage appropriate dilution of cytokines were added and then placed in serum free media. The concentration and time point of exposure to these cytokines for MMP induction have been established previously in our laboratory in several cell lines11,12. After 48-hours, supernatants from stimulated and control HSG cells were collected, centrifuged to remove cells and debris and stored at $-80 \circ \mathrm{C}$ for subsequent analyses.

\section{Result}

Analyses of supernatant from cytokine treated cells were done by SDS-PAGE Zymography and Western blotting. Increased $92 \mathrm{kDa}$ gelatinase activity was detected in cytokine treated cells compared to untreated HSG cells and activity were highest in IL$1 \beta$ treated cells compared to individually treated cells by $\mathrm{TNF}-\alpha$ and its combination with $\mathrm{IL}-1 \beta$. Western blotting was performed to see the involvement of MMP-1, MMP-3 which has been shown to present in increased concentration in the microenvironment of pSS by previous immunohistochemical study in our laboratory. MMP1 and 3 were found to be present in a statistically significant concentration in tissue taken from patients with pSS compared to control subjects.

HSG cells were cultured in serum free media and stimulated with proinflammatory cytokines TNF- $\alpha$, TNF- $\alpha+I L-1 \beta, I L-1 \beta$, (MCP-1 and IL- 8 not shown) over a 48 hours time period. Preliminary experiments revealed that even low concentration of fetal bovine serum (2-5\%) would induce matrix metalloproteinase and tissue inhibitor of metalloproteinase without addition of any other stimuli. Hence, all subsequent analyses were performed in serum free culture conditions.

SDS-PAGE gelatin zymography was performed to determine the gelatinolytic activity in culture supernatant of HSG cells stimulated with proinflammatory cytokines TNF- $\alpha, \mathrm{TNF}-\alpha+\mathrm{IL}-1 \beta$, IL-
$1 \beta$, MCP-1 and IL-8. Enzymatic activity was identified as clear zones (lytic bands) in a blue stained background. A gelatinolytic band was observed at 92- kDa, corresponding to MMP-9. The zymography bands were quantitated by a densitometer (Bio-Rad). Semi quantitative data were generated on the relative induction of gelatinase $B$ with respect to unstimulated HSG cells. MMP-9 protein was induced 2 -fold by the addition of TNF- $\alpha$ alone (Figure 1, lane 3 ), and IL-1 $\beta$ alone (Figure 1, lane 5) for 48 hours. Minor alteration of band intensity was noted when TNF- $\alpha+\mathrm{IL}-\beta$ combination were used (Figure 1, lane 4). However, this induction was less compared to cytokines added individually. Phorbol myristate acetate used as a positive control stimulus enhanced MMP-9 activity further (Figure 1, lane 6 ). The addition of MCP-1 and IL-8 had not inductive effect on MMP-9 activity (not shown). Likewise unstimulated HSGs cells displayed low to none gelatinolytic activity (Figure 1, lane 2).

Analyses of supernatant from cytokine treated HSG cells were done by Western blotting also for MMP-3 and MMP-1. In case of MMP-3, a immunoreactive band was precipitated, that migrated to $49-\mathrm{kDa}$. Densitometry (Bio-Rad) was done to quantitate band intensity. MMP-3 was induced more than 5 times by the addition of TNF- $\alpha$ (Figure 2, lane 3 ) and IL-1 $\beta$ added individually (Figure 2, lane 5). PMA has induced MMP-3 expression but far below extent as the cytokines (Figure 2, lane 3, 5, 6).

An MMP-1 immunoreactive band was precipitated, that migrated to $55-\mathrm{kDa}$, when analyses of supernatant from cytokine treated cells were done by Western blotting for MMP-1 also. Although constitutively expressed (Figure 3 , lane 1), the intensity of the immunoreactive band for MMP-1 was more than 10 fold induced by TNF- $\alpha$ (Figure 3 , lane 2 ) and IL-1 $\beta$ (Figure 3 , lane 4 ). The band intensity of $\mathrm{IL}-1 \beta$ is more prominent compared to TNF- $\alpha$ (Figure 3 , lane 2,4$)$. While the combination of cytokines TNF- $\alpha+$ IL- $1 \beta$ enhanced MMP- 1 above constitutive levels ( 8 fold induced) (Figure 3 , lane 3 ) it was not an additive effect.

The current study is the first to show MMP-1 and MMP- 3 protein expression by Western blotting from culture supernatant of HSG cells following stimulation with these cytokines. In the present study MMP-9 was detected in HSG conditioned medium after stimulation with pro inflammatory cytokines TNF- $\alpha$ and IL $-1 \beta$. However, it's functionally and structurally enzyme MMP-2 was not. 


\section{Discussion}

Cytokines are protein molecules and known to have immunomodulatory functions and also known to play a vital role in cell-to cell communications, inflammation, signal proliferation, differentiation and cell death13,14. Cytokines are implicated in many chronic inflammatory and autoimmune diseases and aberrant expression of cytokines has been found in serum and at involved tissue sites ${ }^{15}$. Autoimmune diseases often show excessive production of IL-1 $\beta$, $\mathrm{IL}-12, \mathrm{TNF}-\alpha$ and IFN- $\gamma^{16}$. The proinflammatory cytokines TNF- $\alpha$ and $\mathrm{IL}-1 \beta$ play an important role in many inflammatory and autoimmune diseases 17;18;19;20. TNF- $\alpha$ is produced by lymphocytes, macrophages 21 , epithelial cells 22 and IL- $1 \beta$ is produced by epithelial cells 22,23 and macrophages 24 . The proinflammatory cytokines (TNF- $\alpha$ and IL-1 $\beta$ ) have been found to induce expression of matrix metalloproteinase in many autoimmune diseases 25,26 including Sjogren's syndrome 3,27 . They also likely to regulate expression of MMP genes in periodontal tissue 28 . It has been shown that $T N F-\alpha$ stimulate collagenase production in human synovial cells and dermal fibroblasts and anti tumor necrosis factor alpha antibody CA2 decreased the serum level of MMP-3 significantly in Rheumatoid arthritis. MMP-1 level was also reduced but less than MMP-329. IL-1 $\beta$ mediate induction, upregulation, and expression of MMPs. Abundant expression of cytokines has been found in salivary glands in patients with Sjogren's syndrome and local mononuclear cells and epithelial cells are involved in this production $22 ; 23 ; 30 . \mathrm{IL}-1 \beta$ and TNF- $\alpha$ though unrelated and bind to distinct receptors, but they share many biological functions. This could be possible because distinct cytokine receptor interactions use the same signaling system inside the cells ${ }^{31}$. It has also been reported that cytokine combinations can work together in an organ or tissue to produce coordinated effects including expression of MMPs and TIMPs25, 26, 32 .

Cytokine expression differs between acinar and ductal epithelial cells of MSGs from patients with SS. Oxholm et $\mathrm{al}^{33}$ examined 7 (seven) cytokines in defined parts of labial salivary glands of patients with pSS and controls. They found acinar epithelium to express IL-1 $\beta$, lymphocytes to express IL-1 $\beta$, IL-6, and TNF- $\alpha$. However, ductal epithelium expressed IL-1 $\beta, \quad I L-6, \quad$ IFN- $\gamma$ and TNF- $\alpha$. Ductal epithelial cellular expression of these cytokines were more intense in LSG (labial salivary glands) of patients with pSS. "IL-1 $\ldots$ IL-4, TNF- $\beta$ could not be detected in any tissue specimens 33 . Cauli et al 34 detected strong expression of IL-1 $\beta, \mathrm{IL}-1 \alpha, \mathrm{IL}-8, \mathrm{GM}-\mathrm{CSF}$ and
TGF- $\beta$ in the ducts of the minor salivary glands of patients with SS. Ductal epithelial cells showed intense expression of IL-1 $1 \beta$, IL-6, IFN- $\gamma$ and TNF- $\alpha$ in LSG of patients with pSS but IL- $1 \alpha$, IL- 4 and TNF- $\beta$ could not be detected in any specimen from patients with pSS or controls ${ }^{34}$. The intensity of staining for IL-1 $\beta$ was significantly more in patients with SS then in patients with chronic sialadenitis and normal control subjects.

MMPs may play an important role in pathogenesis of SS4,27,35. Cytokines are potent inducers of MMPs. Cytokine induced MMP production has been investigated in different epithelial cell lines in SS 3,27 and it has been found that they play a regulatory role on elaboration of MMPs particularly MMP-2 and 9 in $\mathrm{SS}$. There is a complex interaction between cytokine expression and MMP production. Some of the effectors functions of activated MMPs on cytokine production include, they help in secretion of active TNF by cleavage of the membrane bound form 36 , and they help in proteolytic shedding of some cytokine receptors 37 .

Elevated levels of many cytokines, including IL-1 $1 \beta$ and TNF- $\alpha$ has been reported in salivary gland epithelial cells of patients with $S S$ by several authors22,33. Expression of MMP-2 and 9 by stimulation with proinflammatory cytokines has been shown by $\mathrm{Wu}$ et $\mathrm{al}^{3}$. Human salivary gland cell line (HSG) was used by Wu et $\mathrm{al}^{3}$ as an in-vitro model to study the role of IFN- $\gamma+/-$ TNF- $\alpha$ on MMP-2 and 9 productions. It was shown that IFN- $\gamma+1-\mathrm{TNF}-\alpha$ expressed increased MMP-2 and MMP-9 gelatinolytic activity, protein and RNA levels when the HSG cells were treated with IFN- $\gamma+1-\mathrm{TNF}-\alpha$. These data suggest a role for cytokines in regulating MMP production by salivary epithelial cells and thus indicate a potential role of salivary epithelial cells in the pathogenesis of $\mathrm{SS}^{3}$.

Our study confirmed the increased expression of MMP-1 and MMP-3 protein band in cytokine treated cells compared to untreated HSG cells. In another study of our group found increased expression of MMP-1 and MMP-3 immunoreactivity among the patients with pSS compared to control subjects. Proinflammatory cytokines are well known for their effects on inflammation and tissue destruction. Both processes have been implicated in the pathophysiology of pSS. It is possible that their tissue destructive capability may be due to their ability to induce MMP. Cytokines are potent inducers of MMPs expressions $3,25,26,38$. The presence of significant amounts of TNF- $\alpha$ and IL-1 $\beta$ in MSGs (minor salivary glands) and lacrimal glands of 
patients with SS has been observed in animal and human studies $33,34,39,40$. Epithelial cells are an important source of cytokines implicated in the pathogenesis of SS2,23.

To date, there have been no previous studies on the modulatory effects of the proinflammatory cytokines (TNF- $\alpha$, and IL-1 $\beta$ on expression of MMP-1 and MMP-3 in SS using HSG cells. The current study is the first to show MMP-1 and 3 protein production in culture supernatant of HSG cells following stimulation with these cytokines (Figure 2 and 3 ). In addition to cytokines, two potent leucocyte chemoattractant chemokines (MCP-1 \& IL-8) were also used to stimulate HSG cells. However, these two chemokines did not increase MMP production, another study from our laboratory indicated their potential involvement in the chronic inflammation and recruitment of leucocytes to the MSGs in SS41.

Only a few studies have demonstrated the effect of cytokines on MMP expression in SS. Wu et $\mathrm{al}^{3}$ detailed the induction of MMP-2 and - 9 in HSG cells after stimulation with IFN- $\gamma$ and /or TNF- $\alpha$ The authors of that study observed low level of MMP-2 activity in media derived from untreated and TNF- $\alpha$ treated HSG cells and little or no MMP-9 activity after similar treatment. Although, a clear increase in band intensity was observed when HSG cells were treated with IFN- $\gamma$ alone or in combination of TNF- $\alpha$. Simian virus 40 immortalized normal human salivary gland cells (with acinar and ductal cell phenotypes) treated with TNF- $\alpha$ and $\mathrm{IL}-1 \beta$ demonostrated enhanced MMP-2 activity. However, clones with ductal phenotypes were not responsive after similar treatment27. In the present study MMP-9 was detected in HSG conditioned medium after stimulation with TNF- $\alpha$ and IL-1 $\beta$ however, MMP-2 was not. Although this may indicate the absence of expression of MMP-2 by these cells, the present study cannot exclude the probability that this enzyme is present but below the sensitivity of the assay used. The observation of the current study is in agreement with previous studies.

It is concluded that, proinflammatory cytokine IL-1 $\beta$ and TNF- $\alpha$ modulates the expression of MMPs particularly MMP-1, MMP-3, MMP-9 in SS in the setting of HSG cell line. Cytokines particularly IL-1 $\beta$ and TNF- $\alpha$ are responsible for enhanced expression of MMPs especially MMP-1, MMP-3, and MMP-9 as evidenced by these in vitro studies. The enhanced expression of above MMPs could be responsible for perturbation and destruction of epithelial cells characteristic of Sjogren's syndrome.

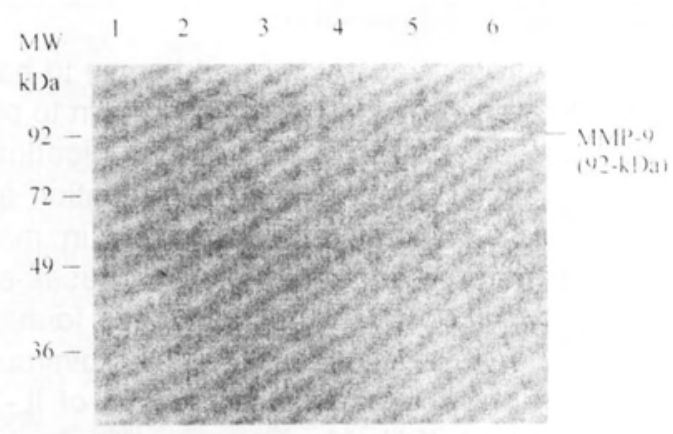

Figure 1: Gelatinolytic activity in culture supernatants from cytokines stimulated HSG cells. Conditioned media from control (lane 2), TNF- $\alpha$ (lane 3), TNF- $\alpha+$ IL-1 $\beta$ (lane 4), IL$1 \beta$ (lane 5) and PMA (lane 6) was analysed by gelatinsubstrate zymography. A moleculer marker (lane 1) was run in adjacent lanes.

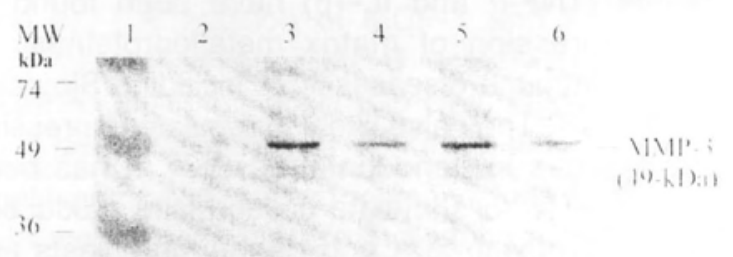

Figure 2: Immunodetection of MMP-3 in culture supernatants from cytokines stimulated HSG cells. Conditioned media from control (lane 2), TNF- $\alpha$ (lane 3), TNF- $\alpha+$ IL-1 $1 \beta$ (lane 4), IL-1 $1 \beta$ (lane 5) and PMA (lane 6) was analysed by Western blotting. A molecular marker was run (lane 1) in adjacent lanes.

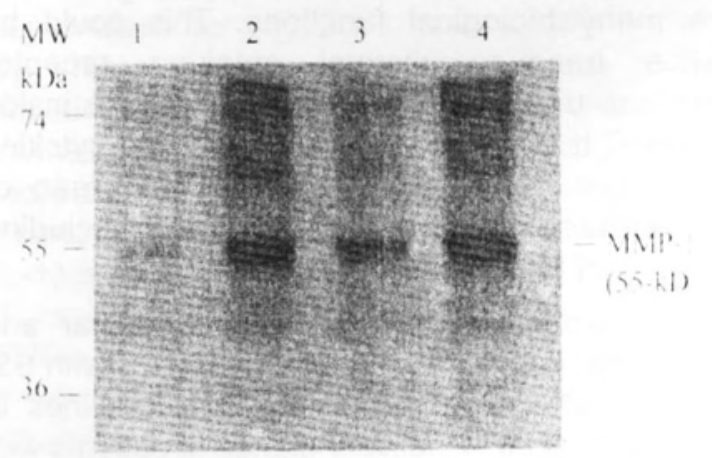

Figure 3: Immunodetection of MMP-1 in culture supernatants from cytokines stimulated HSG cells. Conditioned media from control (lane 1), TNF- $\alpha$ (lane 2), TNF- $\alpha+$ IL-1 (lane 3 ) and IL-1 $\beta$ (lane 4 ) was analysed by Western blotting. Molecular weight has been shown on left. 


\section{References}

1. Wakefield D, McCluskey P. Eye, In: Bradley J, McCluskey J. eds Clinical immunology. Melbourne. Oxford University Press. 1997:pp 213-34.

2. Manoussakis MN, Moutsopoulos HM. Sjogren's syndrome: autoimmune epithelitis. Baillieres Best Pract Res Clin Rheumatol 2000;14(1):73-95.

3. Wu AJ, Lafrenie RM, Park C et. al. Modulation of MMP2 (gelatinase A) and MMP-9 (gelatinase B) by interferon-gamma in a human salivary gland cell line. J Cell Physiol 1997;171(2):117-24.

4. Konttinen $Y T$, Kangaspunta $P$, Lindy $O$ et. al. Collagenase in Sjogren's syndrome. Ann Rheum Dis 1994;53(12):836-9.

5. Shirasuna K, Sato M, Miyazaki T. A neoplastic epithelial duct cell line established from an irradiated human salivary gland. Cancer 1981;48(3):745-52.

6. Royce LS, Kibbey MC, Mertz P, Kleinman HK, Baum BJ. Human neoplastic submandibular intercalated duct cells express an acinar phenotype when cultured on a basement membrane matrix. Differentiation 1993;52(3):247-55.

7. Wu AJ, Chen ZJ, Tsokos M, O'Connell BC, Ambudkar IS, Baum BJ. Interferon-gammainduced cell death in a cultured human salivary gland cell line. J Cell Physiol 1996;167(2):297-304.

8. Katz J, Nagler R, Barak S et. al. Cytokines modulate interleukin-6 production by human salivary gland cell line. Cell Immunol 1994;159(2):211-9.

9. Daniels PJ, McArthur CP, Heruth DP, Rothberg PG, Pasztor L, Wang Y. Cytokine-mediated stimulation of laminin expression and cell-growth arrest in a human submandibular gland duct-cell line (HSG). Arch Oral Biol 1999;44(7):603-15.

10. Wang S, Cukierman E, Swaim WD, Yamada KM, Baum BJ. Extracellular matrix protein-induced changes in human salivary epithelial cell organization and proliferation on a model biological substratum. Biomaterials 1999;20(11):1043-9.

11. Di Girolamo N, Verma MJ, McCluskey PJ, Lloyd A, Wakefield D. Increased matrix metalloproteinases in the aqueous humor of patients and experimental animals with uveitis. Current Eye Research 1996;15(10):1060-8.

12. Di Girolamo N, Tedla N, Lloyd A, Wakefield D. Expression of matrix metalloproteinases by human plasma cells and B lymphocytes. Eur J Immunol 1998;28(6):1773-84.

13. Feldmann M, Brennan FM, Chantry D et. al. Cytokine assays: role in evaluation of the pathogenesis of autoimmunity. Immunol Rev 1991;119:105-23.

14. Fox RI, Tornwall J, Michelson P. Current issues in the diagnosis and treatment of Sjogren's syndrome. Curr Opin Rheumatol 1999;11(5):364-71.
15.Brennan FM, Feldmann M. Cytokines in autoimmunity. Curr Opin Immunol 1996;8(6):872-7.

16. Prud'homme GJ. Gene therapy of autoimmune diseases with vectors encoding regulatory cytokines or inflammatory cytokine inhibitors. J Gene Med 2000;2(4):222-32.

17. Old LJ. Tumor necrosis factor. Scientific American 1988;258(5):59-60, 69-75.

18. Georgopoulos S, Plows D, Kollias G. Transmembrane TNF is sufficient to induce localized tissue toxicity and chronic inflammatory arthritis in transgenic mice. J Inflammation 1996;46(2):86-97.

19. Dinarello CA. Role of pro- and anti-inflammatory cytokines during inflammation: experimental and clinical findings. J Biol Regul Homeost Agents 1997;11(3):91-103.

20. Gabay C. IL-1 inhibitors: novel agents in the treatment of rheumatoid arthritis. Expert Opin Investig Drugs 2000; 9(1):113-27.

21. Vassalli $P$. The pathophysiology of tumor necrosis factors. Annual Rev Immunol 1992;10:411-52.

22. Fox RI, Kang HI, Ando D, Abrams J, Pisa E. Cytokine mRNA expression in salivary gland biopsies of Sjogren's syndrome. J Immunol 1994;152(11):5532-9.

23. Boumba D, Skopouli FN, Moutsopoulos HM. Cytokine mRNA expression in the labial salivary gland tissues from patients with primary Sjogren's syndrome. Br J Rheumatol 1995;34(4):326-33.

24. Dinarello CA, Wolff SM. The role of interleukin-1 in disease. N Engl J Med 1993;328(2): 106-13.

25. Di Girolamo N, McCluskey PJ, Lloyd A, Wakefield D. Stromelysin (matrix metalloproteinase-3) and tissue inhibitor of metalloproteinase (TIMP-1) mRNA expression in scleritis. Ocular Immunol Inflamm 1995;3(3):181-94.

26. Di Girolamo N, Lloyd A, McCluskey P, Filipic M, Wakefield D. Increased expression of matrix metalloproteinases in vivo in scleritis tissue and in vitro in cultured human scleral fibroblasts. Am J Pathol 1997;150(2):653-66.

27. Azuma M, Motegi K, Aota K, Hayashi Y, Sato M. Role of cytokines in the destruction of acinar structure in Sjogren's syndrome salivary glands. Lab Invest 1997;77(3):269-80.

28. Birkedal-Hansen $\mathrm{H}$. Role of matrix metalloproteinases in human periodontal diseases. J Periodontol 1993;64(5 Suppl):474-84.

29. Brennan FM, Browne KA, Green PA, Jaspar JM, Maini $\mathrm{RN}$, Feldmann M. Reduction of serum matrix metalloproteinase 1 and matrix metalloproteinase 3 in rheumatoid arthritis patients following anti-tumour necrosis factor-alpha (cA2) therapy. $\mathrm{Br} \mathrm{J}$ Rheumatol 1997;36(6):643-50. 
30. Sun D, Emmert-Buck MR, Fox PC. Differential cytokine mRNA expression in human labial minor salivary glands in primary Sjogren's syndrome. Autoimmunity 1998;28(3):125-37.

31. Hamblin AS. Cytokine and cytokine receptors. Oxford University Press, 1993. USA.

32. Horton WE, Udo I, Precht P, Balakir R, Hasty K. Cytokine inducible matrix metalloproteinase expression in immortalized rat chondrocytes is independent of nitric oxide stimulation. In Vitro Cellular \& Developmental Biology. Animal 1998;34(5):378-84.

33. Oxholm P, Daniels TE, Bendtzen K. Cytokine expression in labial salivary glands from patients with primary Sjogren's syndrome. Autoimmunity 1992;12(3):185-91.

34. Cauli A, Yanni G, Pitzalis C, Challacombe S, Panayi GS. Cytokine and adhesion molecule expression in the minor salivary glands of patients with Sjogren's syndrome and chronic sialoadenitis. Ann Rheum Dis 1995;54(3):209-15.

35. Konttinen $\mathrm{YT}$, Halinen S, Hanemaaijer $\mathrm{R}$ et. al. Matrix metalloproteinase (MMP)-9 type IV collagenase/gelatinase implicated in the pathogenesis of Sjogren's syndrome. Matrix Biol 1998;17(5):335-47.

36. Gearing AJ, Beckett P, Christodoulou M et. al. Processing of tumour necrosis factor alpha precursor by metalloproteinases. Nature 1994;370(6490):555-7.

37. Xia M, Leppert D, Hauser SL et. al. Stimulus specificity of matrix metalloproteinase dependence of human $T$ cell migration through a model basement membrane. J Immunol 1996;156(1):160-7.

38. Ries C, Petrides PE. Cytokine regulation of matrix metalloproteinase activity and its regulatory dysfunction in disease. Biol Chem Hoppe-Seyler 1995;376(6):345-55.

39. Hamano H, Saito I, Haneji N, Mitsuhashi Y, Miyasaka $\mathrm{N}$, Hayashi $\mathrm{Y}$. Expressions of cytokine genes during development of autoimmune sialadenitis in MRL/lpr mice. Eur J Immunol 1993;23(10):2387-91.

40. Saito I, Terauchi K, Shimuta M, Nishemura S, Toshino $\mathrm{K}$, Takeuchi T, Tsubota K. Expression of cell adhesion molecules in the salivary and lacrimal glands of Sjogren's syndrome. J Clin Lab Anal 1993;7(3):180-7.

41. Cuello C, Palladinetti $P$, Tedla $N$ et. al. Chemokine expression and leucocyte infiltration in Sjogren's syndrome. Br J Rheumatol 1998;37(7):779-83. 